University of Nebraska - Lincoln

DigitalCommons@University of Nebraska - Lincoln

Publications, Agencies and Staff of the U.S.

Department of Commerce

U.S. Department of Commerce

2-1991

\title{
Geographic Variation in Sea Otters, Enhydra lutris
}

Don E. Wilson

National Museum of Natural History, Smithsonian Institution, Washington, DC

Michael A. Bogan

U.S. Fish and Wildlife Service, 4512 McMurray Avenue, Ft. Collins, CO

Robert L. Brownell Jr.

U.S. Fish and Wildlife Service, rlbcetacea@aol.com

A. M. Burdin

Pacific Scientific Research Institute of Fisheries and Oceanography, Petropavlovsk-Kamchatsky, USSR

M. K. Maminov

Pacific Scientific Research Institute of Fisheries and Oceanography, Vladivostok, USSR

Follow this and additional works at: https://digitalcommons.unl.edu/usdeptcommercepub

Part of the Environmental Sciences Commons

Wilson, Don E.; Bogan, Michael A.; Brownell, Robert L. Jr.; Burdin, A. M.; and Maminov, M. K., "Geographic Variation in Sea Otters, Enhydra lutris" (1991). Publications, Agencies and Staff of the U.S. Department of Commerce. 90.

https://digitalcommons.unl.edu/usdeptcommercepub/90

This Article is brought to you for free and open access by the U.S. Department of Commerce at DigitalCommons@University of Nebraska - Lincoln. It has been accepted for inclusion in Publications, Agencies and Staff of the U.S. Department of Commerce by an authorized administrator of DigitalCommons@University of Nebraska - Lincoln. 


\title{
GEOGRAPHIC VARIATION IN SEA OTTERS, ENHYDRA LUTRIS
}

\author{
Don E. Wilson, Michael A. Bogan, Robert L. Brownell, Jr., \\ A. M. Burdin, and M. K. Maminov \\ National Museum of Natural History, Smithsonian Institution, Washington, DC 20560 (DEW) \\ U.S. Fish and Wildlife Service, 4512 McMurray Avenue, Ft. Collins, CO 80525 (MAB) \\ U.S. Fish and Wildlife Service, P.O. Box 70, San Simeon, CA 93542 (RLB) \\ Pacific Scientific Research Institute of Fisheries and Oceanography, \\ Petropavlovsk-Kamchatsky, USSR (AMB) \\ Pacific Scientific Research Institute of Fisheries and Oceanography, \\ Vladivostok, USSR (MKM)
}

\begin{abstract}
Univariate and multivariate analyses of 20 skull characters of 304 adult sea otters from throughout the geographic range strongly suggest that three subspecies should be recognized. The nominate form, Enhydra lutris lutris, occurs from the Kuril Islands north to the Commander Islands in the western Pacific Ocean. Individuals of E. l. lutris are characterized by large size and wide skulls with short nasal bones. E. $l$. nereis is found along the California coast and off San Nicolas Island, where the species recently has been reintroduced from coastal California. Specimens of $E$. $l$. nereis have narrow skulls with a long rostrum and small teeth, and usually lack the characteristic notch in the postorbital region found in most specimens of the other two subspecies. A new subspecies described by Don E. Wilson in this report, occurs throughout the Aleutian Islands and southward in the eastern Pacific to Washington. Specimens of the new subspecies are intermediate in size in most, but not all, characters and have longer mandibles than either of the other two subspecies.
\end{abstract}

Sea otters (Enhydra lutris) were known only to indigenous peoples on both Pacific coasts until the late 17th century when Russian explorers of Kamchatka-Atlasov, Anciferov, Kozirevskiy, and others-brought reports back to Russia near the beginning of the 18th century. In the New World, Padre Taraval discovered them on Cedros Island in 1737 (Harris, 1968). Steller (1751) recorded the first detailed description of the sea otter, based on observations during the winter of 1741-1742 when he overwintered on what was to become known as Bering Island during Vitus Bering's second Kamchatka expedition. The archives of the USSR Academy of Science contain a manuscript describing a male and female sea otter by S. P. Krasheninikov in 1738 (Descriptio avium, animalium et vegitabilium).

Sea otters originally were distributed from the northernmost Japanese Islands through the Kuril Islands, Kamchatka Peninsula, the Commander Islands, the Aleutians, peninsular and south coastal Alaska, and southward to Baja California, Mexico (Fig. 1). This range has been reduced considerably, principally at both extremes of the original distribution. Populations off the British Columbia, Washington, and Oregon coasts were extirpated by fur hunters during the 18th and 19th centuries, and animals from Alaska were reintroduced into these areas between 1951 and 1972 by the Alaska Department of Fish and Game (Jameson et al., 1982). Fortunately, a few museum specimens still exist from pre-reintroduction populations.

This revision is the result of a joint study of material from throughout the range of the sea otter, and responsibility is shared equally by the authors with the exception of the description of the new subspecies. This description is solely Don E. Wilson's work, which obviates the necessity of citing a scientific name with five authorities.

Taxonomic history.-Steller's (1751) name, Lutra marina, was binomial but pre-Linnaean. The correct name of the species dates from Linnaeus (1758), who based his Mustela lutris in part on Steller's account. Linnaeus (1758) listed the habitat as Asia and America septentrionali, and subsequent authors have listed the type locality as either Kamchatka or Bering Island. Thomas (1911:138) fixed the type locality as "Kampchatka." Subsequently and without reference to Thomas (1911), Barabash-Nikiforov (1947) argued that the Commander Islands should be the type locality, because most of Steller's observations were from there, rather than from Kamchatka. 


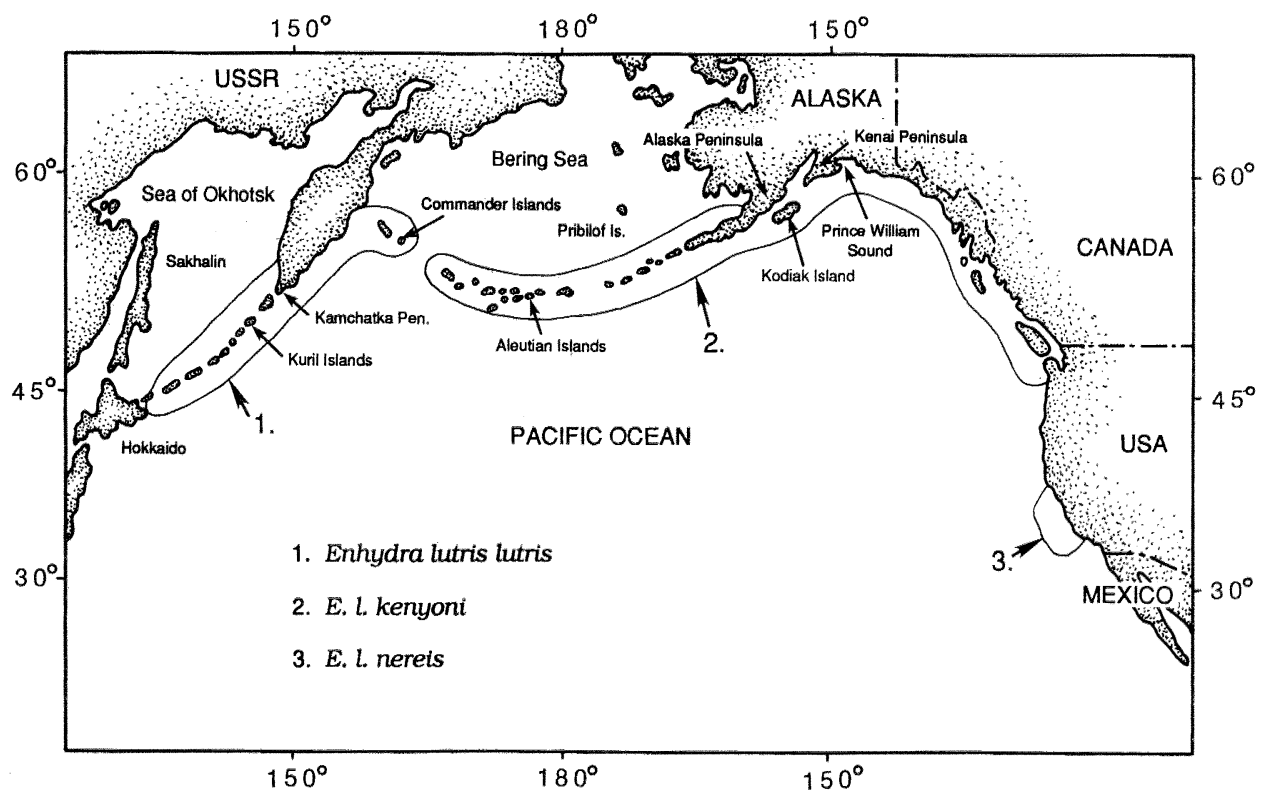

FIG. 1.-Present distribution of Enhydra lutris.

Linnaeus' (1758) genus Mustela encompassed all members of the Family Mustelidae known at that time. Pallas (1831) placed the species in the genus Phoca in an attempt to ally it with the Pinnipedia. Oken (1816) separated the species into a new genus by naming it Pusa orientalis. However, Pusa is preoccupied by Pusa Scopoli, a name now in the synonymy of Phoca, a genus of seals. Furthermore, Oken's names are unavailable according to the International Commission on Zoological Nomenclature. The genus Enhydra, as proposed in 1822 by Fleming, is the oldest available name. The only other generic name used was Latax Gloger (1827), a renaming of Pusa Oken, but clearly a junior synonym of Enhydra Fleming.

Two additional specific names have been applied, including Lutra stelleri Lesson (1827), a renaming apparently prompted by Lesson's belief that Erxleben's (1777) Lutra marina was actually a land otter. The final specific name that needs consideration is also the most troublesome. The name Lutra gracilis was used by both Bechstein and Shaw in 1800. These authors, the former in Germany, and the latter in England, applied the name to an animal first described by Pennant (1793) under the common name "slender otter." We must assume that both names were published on 31 December 1800 , because there is no evidence of the exact dates of publication. Bechstein's (1800) treatise is a German translation of Pennant, with emendations and additions. The only emendation to the slender otter account is a footnote reading Lutra gracilis $\mathrm{B}$. This footnote indicates that Bechstein (1800) was providing a scientific name for the species in question. Shaw (1800) used the name without comment. Therefore, we select Lutra gracilis Bechstein, 1800, as having precedence over Lutra gracilis Shaw, 1800.

The first subspecies described was Enhydra lutris nereis (Merriam, 1904), the California sea otter. Barabash-Nikiforov (1947) recognized three subspecies: E. l. gracilis from the Kuril Islands north to Lopatka Point, the southern tip of the Kamchatka Peninsula; E. l. lutris from the northeastern coast of the Kamchatka peninsula to the northwestern coast of North America; and E. l. nereis from the coast of California.

Barabash-Nikiforov (1947) had little material on which to base his systematic revision. $\mathrm{He}$ based the recognition of E. l. gracilis mainly on differences in hair color and form. He only had pelt scraps from Kamchatka, but he relied heavily on Unungun hunters from the Commander Islands who professed to be able to differentiate the two forms easily. Barabash-Nikiforov (1947) also compared six Kamchatkan and 10 Commander Island skulls and had measurements of five 
animals from the Aleutian Islands supplied by Remington Kellogg of the United States National Museum (USNM). He had no material from the Kuril Islands, but assumed that otters from there also represented E. . gracilis. His overall conclusion (Barabash-Nikiforov, 1947:22) was that "The relationships between the sea otters of the Kuril Islands, the Aleutian group, and the west coast of North America must be clarified in order to determine the range boundaries of these subspecies."

Stroganov (1962:205) suggested that E. l. gracilis, as recognized by Barabash-Nikiforov (1947), was a composite: "The number of subspecies has not been precisely established. There are probably at least five. Two or three subspecies inhabit the Soviet Union." He restricted the nominate form to the Commander Islands, and E. $l$. gracilis to the southern Kuril Islands. Stroganov (1962:207) also provided a complete description and diagnosis of the animals from the southern tip of the Kamchatka Peninsula, but failed to name them: "It is not to be denied that systematic differences do occur between this and the south Kamchatka sea otter, but until specimens of the south Kuril sea otter are studied in detail, I refrain from giving a taxonomic name to the otter inhabiting the southern tip of Kamchatka." After conducting such studies, we affirm that Stroganov's (1962) restraint was admirable.

Meanwhile, on the other side of the Pacific, the merits of recognizing E. l. nereis were debated by various workers. Grinnell et al. (1937:287) compared the holotype of $E$. l. nereis with "an example ... of the same sex and age" from the Aleutian Islands and found sufficient differences to warrant recognition of the two forms. Scheffer and Wilke (1950) studied 46 specimens from the Aleutian Islands and 10 from southeastern Alaska, Washington, Oregon, and California, and carefully compared each of the diagnostic features used by Merriam (1904) in the original description. They decided (p. 272) that "Neither on the basis of demonstrable variation nor on the grounds of geographical isolation is there support for a southern subspecies of the sea otter."

Kenyon (1969) examined hundreds of sea otters from Alaska and the Aleutian Islands as the U.S. Fish and Wildlife Service fur seal and sea otter biologist from the late 1940s to the early 1970s. He agreed with Scheffer and Wilke (Kenyon, 1969:5): "Because of the variation among animals I have seen, the meager specimen material used to date in defining races, and the similarity of habitats occupied by the sea otter throughout its geographic range, it is not possible, without further study, to distinguish racially distinct populations which might exist."

Roest (1971:135) studied 50 specimens from California and 214 from Alaska and concluded: "The subspecies E. l. nereis is therefore considered valid as the proper designation of the southern sea otter along the California coast." Roest (1973) examined additional material from Prince William Sound in southern Alaska, and decided that these formed an intermediate population, resulting in a cline of geographic variation with $E$. $l$. nereis on one extreme and animals from the Aleutian Islands on the other. He recommended placing E. l. nereis in the synonymy of the nominate form, and supported that view in subsequent papers (Roest, 1976; A. I. Roest, in litt.).

Davis and Lidicker (1975:436) criticized Roest's (1973) interpretations and presented equally cogent arguments for recognizing the subspecies $E$. l. nereis: "We therefore propose that three subspecies continue to be recognized for this unique and important mammal."

The confusion surrounding the validity of $E$. $l$. nereis caused concerns during the early phases of the Endangered Species Program. In fact, some authors of taxonomic papers became involved in polemics over management concerns that may be affected by the recognition of the California population as a distinct subspecies. A complete reappraisal of sea otter taxonomy, based on material from throughout the species' range, should be useful in achieving a classification that best describes the geographic variation in the species.

\section{Materials and Methods}

A joint Marine Mammal Project under the USA-USSR Environmental Protection Agreement resulted in an opportunity to conduct an analysis of sea otter populations. In 1986, 277 specimens of sea otters were examined in the Soviet Union from throughout the western Pacific range including several of the Kuril Islands, the Kamchatka Peninsula, and Bering Island. Another 88 specimens were examined in the National 
Museum of Natural History in Washington, D.C., from the eastern Pacific range including the Aleutian Islands, Alaska, Oregon, and California. In addition, Aryan Roest loaned us the original measurement data from specimens he had used in his earlier studies. A total of 236 specimens from the Soviet Union, 84 from Alaska and northwestern North America, and 48 from California was used in a series of univariate and multivariate analyses.

Institutions housing specimens listed under specimens examined are: American Museum of Natural History, New York (AMNH); California Academy of Sciences, San Francisco (CAS); California Department of Fish and Game (CFG); California Polytechnic State University, San Luis Obispo (CPSU); Loma Linda University, Loma Linda, California (LLU); Moss Landing Marine Laboratory, Moss Landing, California (MLinL); Museum of Vertebrate Zoology, University of California, Berkeley (MVZ); National Museum of Natural History, Washington, D.C. (USNM); National Science Museum, Tokyo (NSM); Pacific Grove Museum, Pacific Grove, California (PGM); Pacific Scientific Research Institute of Fisheries and Oceanography, Vladivostok, USSR (TINRO); Royal British Columbia Museum, Vancouver (RBCM); Sacramento State University, Sacramento, California (SSU); San Diego Museum of Natural History, San Diego, California (SDMNH); Santa Barbara Museum of Natural History, Santa Barbara, California (SBMNH).

Characters measured.-The following data were obtained for each skull: condylobasal length-from anterior edge of premaxillae to posteriormost surface of occipital condyle; zygomatic width—greatest distance across zygomatic arches; mastoidal width-greatest distance across mastoid processes; postorbital constriction width-shortest distance across skull behind postorbital processes; interorbital width-shortest distance across top of skull between upper margins of orbits; nasal-suture length-length of suture along midline between nasal bones; palatal width-maximum distance between inner edges of alveoli of upper molars; diameter of upper canine-greatest diameter of upper canine, taken at or just below alveolar margin with tooth in place; length of upper molar-greatest length across surface of $\mathrm{M} 1$; mandibular length-length of mandible, from posteriormost part of angular process to anteriormost part of mandibular symphysis; width of first lower molar-maximum distance across crown of $\mathrm{ml}$; coronoidal length-anterior-posterior length of coronoid process, measured just above articular process; frontal notch-distinct constriction present in postorbital region (scored as 3), suggestion of notch (scored as 2), or absence of notch (scored as 1); coronoidal projectioncoronoid with concave posterior edge and tip posterior to articular process (3), coronoid with straight, vertical posterior edge (2), or coronoid with convex posterior edge and tip anterior to articular process (1); sagittal crest—sagittal crest either straight (0) or curved (1); occipital crest-left side longer than right (1), right side longer than left (2), or both sides the same length (3); paroccipital foramina-absent (0), right side only (1), left side only (2), both sides (3); foramen lacetum - absent (0), right side only (1), left side only (2), both sides (3); masseteric fossa-anterior edge of masseteric fossa posterior to $\mathrm{m} 2$ (1), even with $\mathrm{m} 2$ (2), anterior to $\mathrm{m} 2$ (3); palatal notch-posterior edge of palate even (1), posterior edge of palate with a midventral notch (2), posterior edge of palate with a midventral posterior projection (3).

All characters were measured with dial calipers and recorded to the nearest $0.1 \mathrm{~mm}$. Data were analyzed on a personal computer by use of BIO $\sum$ TAT software. Only adult specimens were used for the analyses, and males and females were analyzed separately because of sexual dimorphism (Roest, 1985). This study extended Roest's $(1971,1973,1976)$ previous work by duplicating his measurements on the Soviet and Alaskan material and using his original data on the California and some of the intermediate specimens that he suggested were indicative of clinal variation. Slight differences in technique may have affected some of the subsequent analyses, but such discrepancies are not likely to change our overall conclusions.

The primary data set was subjected to a variety of univariate analyses, and, using various subsets of both specimens and characters, in several multivariate analyses. Character subsets that minimized linearity (redundance) were used in the final series of discriminant-function analyses (Pimentel and Smith, 1986). These analyses form the basis of our taxonomic conclusions. Some character combinations were used to maximize sample sizes by allowing the inclusion of specimens that otherwise might have been rejected because of missing data. Condylobasal length, coronoidal length, paroccipital foramina, foramen lacetum, masseteric fossa, and palatal notch were eliminated from the final multivariate analyses.

Condylobasal length is a useful measure of overall size when used alone, but it is highly correlated with many of the other characters and eliminating it from some of the multivariate analyses reduced redundancy. Coronoidal length was missing from several specimens from critical areas and was eliminated to increase overall sample sizes for some analyses.

Paroccipital foramina, foramen lacetum, masseteric fossa, and palatal notch showed considerable variation in all samples, but their possible usefulness was hampered by what appeared to be some correlation with age. Only adults were used, but sea otter skulls continue changing with age in aspects such as bone deposition on crests and other ways that may have affected those character states. 


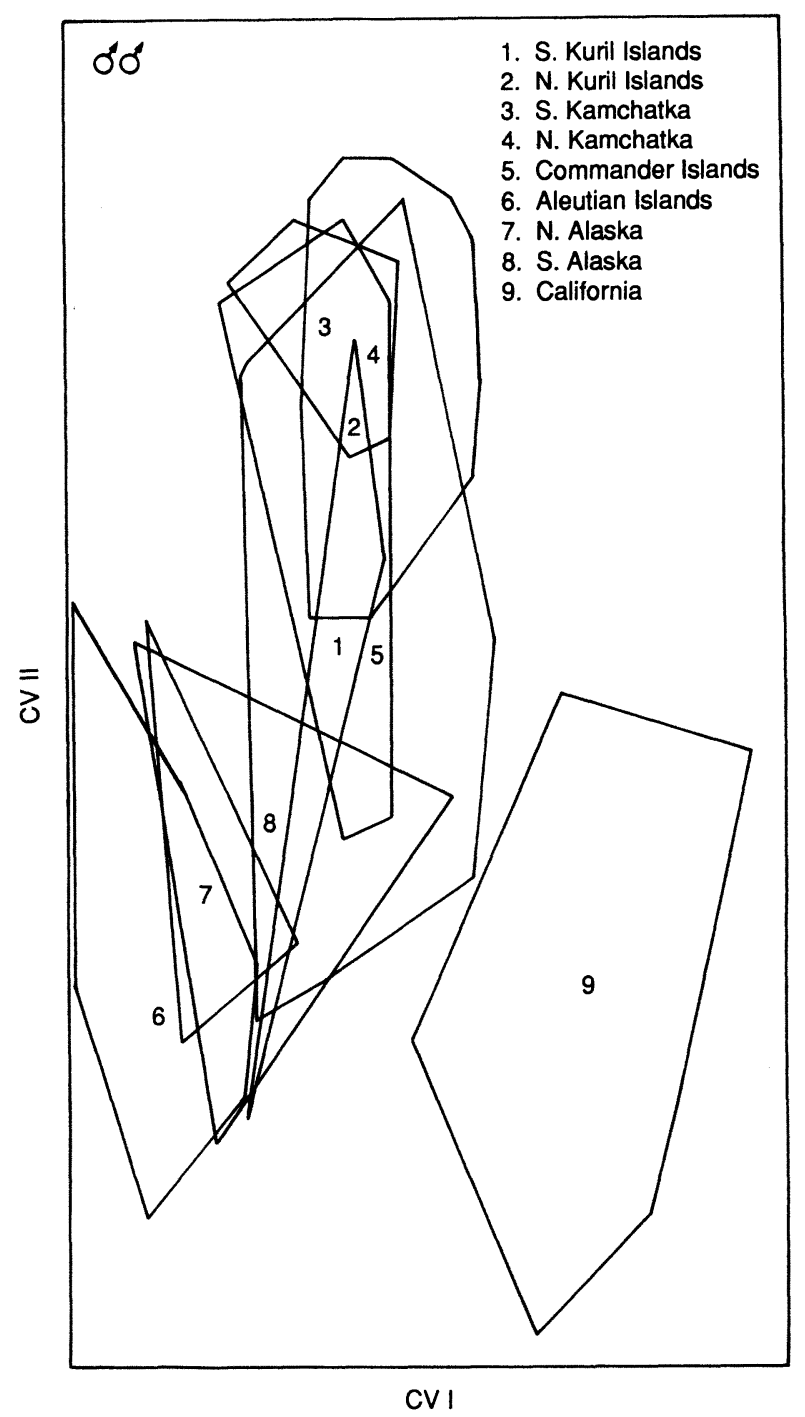

Fig. 2.-Projections of nine locality groups of 197 male sea otters on the first two canonical variates. Polygons enclose scores for all individuals within a locality group, and numbers are placed on group centroids.

\section{Results AND Discussion}

Multivariate analyses.-Originally, animals were grouped into nine geographic localities as follows: unknown Asian Pacific, southern Kuril Islands (Uruppu, Iturup, Chernye Brabya), northern Kuril Islands (Onnekotan, Paramushiro, and Shumushu near Lopatka Point), Kamchatka Peninsula (Lopatka Point), Commander Islands, Aleutian Islands, northern Alaska (Peninsula), southern Alaska, and California. A discriminant function analysis of 197 males from these localities suggested that California animals were the most distinct, because that sample was the only group that showed no overlap with the remaining groups (Fig. 2).

Of the 197 specimens, $168(85 \%)$ were classified correctly and $29(15 \%)$ were misclassified (Table 1). All Aleutian specimens and all California specimens were correctly allocated. Most of the misclassifications were among the specimens from the USSR. Animals of unknown provenance were removed, samples from northern and southern Alaska were combined because they over- 
TABLE 1.-Classification table for analysis based on nine groups of male sea otters. Rows are actual and columns are predicted groups.

\begin{tabular}{clrllrrrrrrr}
\hline Number & \multicolumn{1}{c}{ Group } & $\boldsymbol{n}$ & $\mathbf{1}$ & $\mathbf{2}$ & $\mathbf{3}$ & $\mathbf{4}$ & $\mathbf{5}$ & $\mathbf{6}$ & $\mathbf{7}$ & $\mathbf{8}$ & $\mathbf{9}$ \\
\hline 1 & Unknowns & 3 & & & & 1 & 1 & & & 1 & \\
2 & South Kurils & 11 & & 3 & & 5 & 3 & & & \\
3 & North Kurils & 12 & & 1 & 6 & 5 & & & & \\
4 & Kamchatka & 43 & & 1 & 1 & 38 & 3 & & & \\
5 & Commanders & 67 & & & & 4 & 62 & & 1 & & \\
6 & Aleutians & 27 & & & & & & 27 & & & \\
7 & North Alaska & 4 & & & & & & 1 & 3 & & \\
8 & South Alaska & 6 & & & & & & 1 & & 5 & \\
9 & California & 24 & & & & & & & & & 24 \\
\hline
\end{tabular}

lapped almost completely, and a second analysis was performed. This analysis resulted in a somewhat clearer representation although the California sample remained the only group with no overlap (Fig. 3a). The two groups from the Kuril Islands also overlapped almost completely, so these groups were combined and the analysis repeated. This resulted in three primary groups: the Kuril Islands, Kamchatka, and the Commander Islands; the Aleutian Islands and Alaska; and California (Fig. 3b).

Samples from the Aleutian Islands and mainland Alaska were combined and the data reanalyzed. The resultant plot separates the three groups more clearly, with California and Alaska each showing no overlap with the other three samples (Fig. 3c).

Combining the Kuril Island sample with that from Kamchatka further improves the groupings (Fig. 3d). The entire series of analyses, particularly this four-group comparison, indicated that animals from the Commander Islands were grouped with animals from the western Pacific rather than with those from the eastern Pacific, where they traditionally have been classified.

Combining the sample from the Commander Islands with the sample from the rest of the Soviet Union yields a grouping with no overlap (Fig. 4a). Of the 189 specimens used in this analysis, $187(99 \%)$ were classified correctly and $2(1 \%)$ incorrectly. One specimen each from the USSR and California were misclassified into the Alaska group, but all of the Alaskan animals were properly allocated.

This series of analyses indicates that the most logical infraspecific classification for E. lutris is to recognize three subspecies. One of these subspecies occurs in the western Pacific from the Kuril Islands north to the Kamchatka Peninsula and on the Commander Islands. Previous workers suggested that the nominate form, E. lutris, occurred from Bering Island eastward through Alaska to the coast of northwestern North America. However, this study clearly shows that animals from Bering Island share affinities with those to the west and south, rather than to the east. Animals from Kamchatka and the Kuril Islands, formerly known as E. l. gracilis, actually represent the nominate form and $E$. $l$. gracilis becomes a junior synonym of $E$. lutris. Animals from California are clearly distinct, and the name $E$. $l$. nereis is available and presently used for these specimens. Animals from the Aleutian Islands and Alaska are without a name, and described by Wilson herein.

Discriminant-function analysis permits classification of unknown specimens into the appropriate group once the original groups are defined. This feature was used to further test the final groupings, and to classify some individuals of unknown or intermediate provenance. Five specimens from unknown or intermediate localities (marked J, K, R, U, and W in Fig. 4a) seemed to be classified correctly with $>70 \%$ probability based on limited information.

The two animals marked BC (Fig. 4a) are specimens from British Columbia, Canada, collected early in this century. They were plotted between groups. Both specimens were classified with animals from the USSR, with probabilities of $83 \%$ and $85 \%$, respectively. This grouping is remarkable, but may be an artifact of an unusually large sample (132) for the USSR population. In the discriminant-function analysis, prior probabilities were set equal to sample sizes to account 

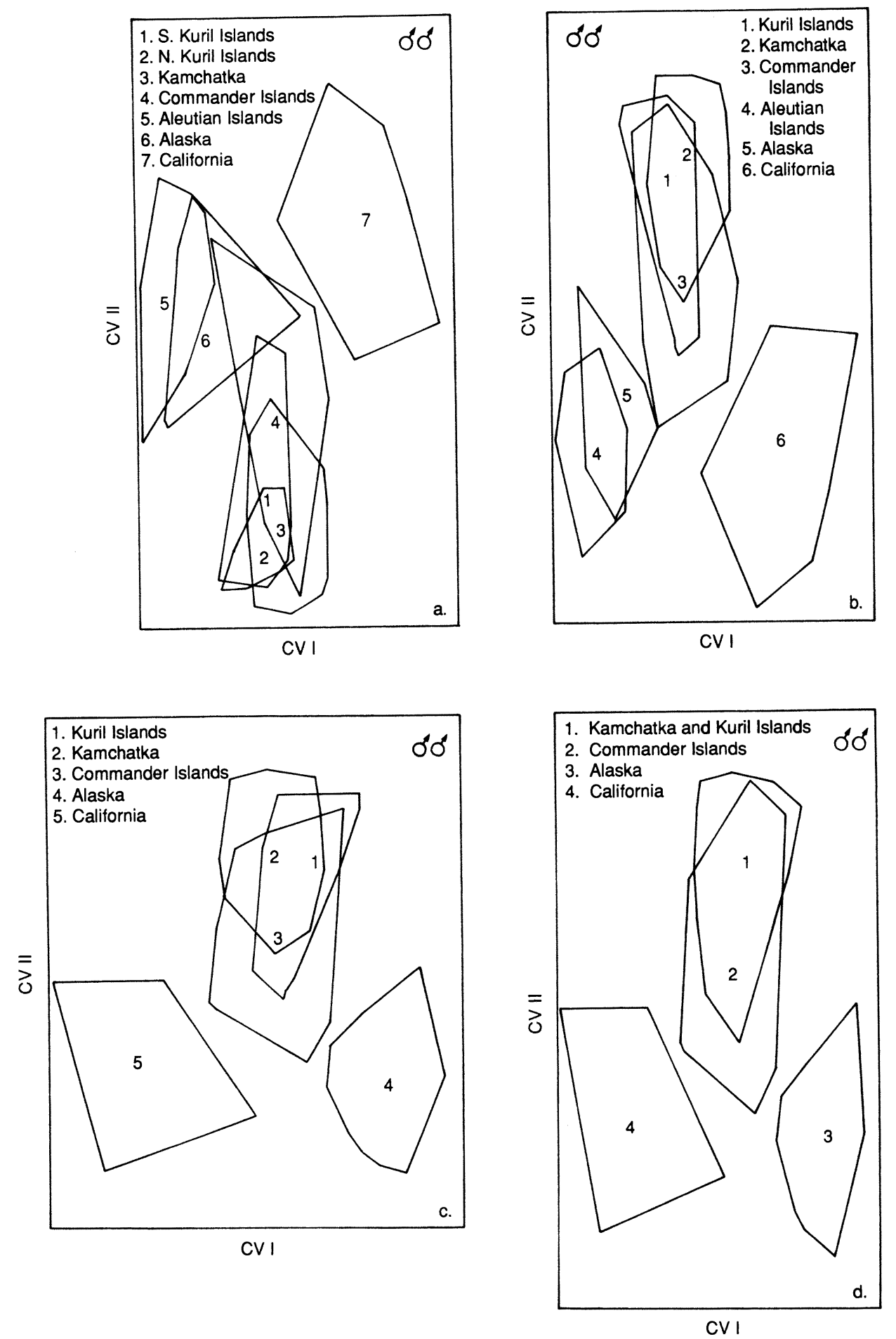

Fig. 3.-Projections of: a, seven; b, six; c, five; and d, four locality groups of 197 male sea otters on the first two canonical variates. Polygons enclose scores for all individuals within a locality group, and numbers are placed on group centroids. 

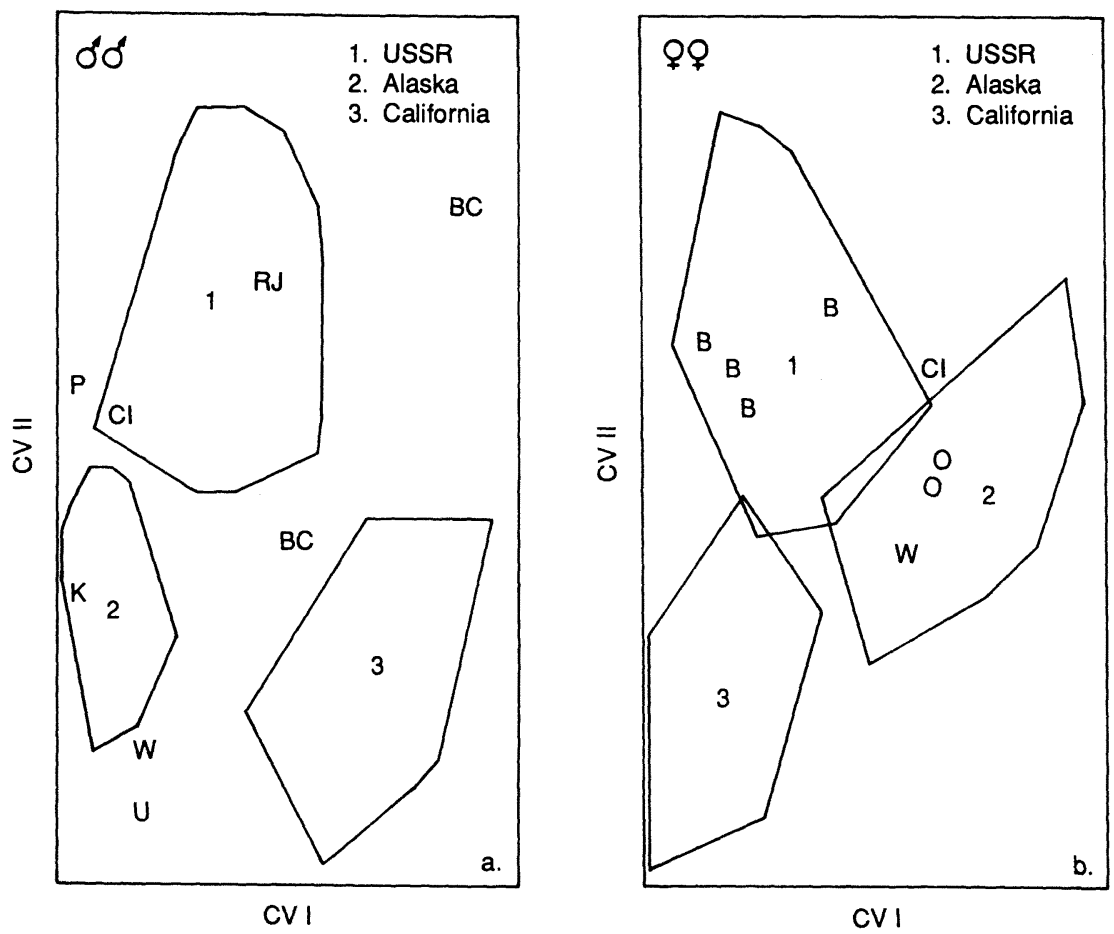

Fig. 4.-Projections of three locality groups of: a, 197 male and b, 93 female sea otters on the first two canonical variates. Polygons enclose scores for all individuals within a locality group, and numbers are placed on group centroids. B, Bering Island; BC, British Columbia, Canada; CI, Copper (Mednyi) Island; K, Kavalga Island; O, Oregon; P, Pribilof Islands; R, Russian unknown; T, Tokyo unknown; U, USNM unknown; W, Washington.

for the disparate sample sizes. Although the Alaskan (32) and Californian (24) samples are sufficient to meet most statistical criteria for robustness, the samples may not encompass all of the variation in those populations, causing some misclassification.

One animal from the Pribilof Islands, marked P in Fig. 4a, was classified with the Alaskan group with a probability of $81 \%$. Another specimen (marked CI) is from Copper (Mednyi) Island, the smaller of the Commander Islands. Although it was included with the USSR samples, it was the only individual from that sample that the computer misclassified, suggesting that it actually belongs to the Alaskan population. Plotting it with the Alaskan sample would improve the separation between those two groups.

A similar analysis for females shows the same fundamental relationships with less separation between the groups (Fig. 4b). Although there were 67 males from Bering Island for the previous analyses, there were only four Bering Island females. Therefore, they were entered as unknowns to test the hypothesis that the population from the type locality belonged with the USSR rather than the Alaskan subspecies. All four (marked B in Fig. 4b) were unequivocally classified with the USSR sample with probabilities ranging from 81 to $88 \%$. This result reinforces the conclusion that the population of sea otters at Bering Island belongs to the same subspecies as animals from Kamchatka and the Kuril Islands.

Two females from Oregon and one from Washington, all collected before reintroductions, were allocated to the Alaskan group with probabilities ranging from 61 to $67 \%$. These probabilities suggested that, although the animals from northwestern North America were somewhat intermediate in morphology between the California and Alaska populations, they were more properly classified with the northern form. 
There also was one female from Copper Island, and it was classified analogous to the male from there discussed earlier. Although the female also was grouped with the western Pacific samples on geographic grounds, it was misclassified with the Alaskan group with a probability of $96 \%$. Reassigning animals from this locality from the USSR to the Alaskan populations would increase the separation between the plots of those two subspecies, but we are reluctant to make that change on zoogeographic grounds. These results indicate the need for additional study of sea otters from Copper Island, or Mednyi as it is known in the Soviet Union.

Past commercial exploitation may have affected present distribution patterns of sea otters. If populations on the Commander Islands were extirpated or reduced to extremely low levels, animals from Kamchatka may have reoccupied Bering Island (a distance of about $200 \mathrm{~km}$ ), and others from the Aleutians may have reoccupied Copper (Mednyi) Island (a distance of about $300 \mathrm{~km})$.

Ognev (1931) suggested that animals found in the early part of this century were but a small remnant of the once abundant fauna of the Commander Islands and other island groups and sea coasts of the northern Pacific. When the crew of the 'St. Peter' visited the Commander Islands in 1741, the Bering Expedition was found to be living through the winter on the flesh of sea otters (Steller, 1751). More than 700 pelts were shipped from Bering Island at that time (Ognev, 1931).

Many traders, lured by stories of the abundance of otters on the islands newly discovered by Bering, rushed to the site. Some 1,600 sea otters were captured on Bering Island in 1745, and 1,350 in 1747 and 1749. The consequences of this rapaciousness quickly became apparent. In 1754-1755, only five sea otters were taken (Ognev, 1931).

Copper (Mednyi) Island was visited less often by hunters and the sea otter survived there for a longer time. In 1754, 790 pelts were taken. Later, due to the near extirpation of this valuable animal, hunting stopped. Only in 1870 were sea otters again recorded near Copper (Mednyi) Island. The reappearance of the otters coincided with their almost complete extermination on the Kuril Islands. Sea otters were formerly found on all the islands, even as far as Kunashiri (Ognev, 1931).

Barabash-Nikiforov (1947) hypothesized that the Commander Islands were repopulated by animals from both the Kuril and Aleutian populations, but he suggested that resultant hybrids occur there now, exacerbating the difficulty of delimiting subspecific boundaries. That the animals now inhabiting Bering and Copper (Mednyi) islands form a single population seems incontrovertible, based on recent studies of inter-island movements by marked animals. The origin of that population, however, is much less clear. Subfossil mandibles from an archaeological site in Kamchatka dating from about 320 years ago share some non-metric characters with modern Kamchatka animals that differ from Commander Island animals. This would suggest that preexploitation populations differed, but concommitant evidence from Aleutian populations is inconclusive (Burdin, 1988).

By the late 1960 s or early 1970 s, the population at Mednyi Island had increased to about 2,500 otters. The population then declined to $900-1,200$ individuals by 1984 . Sea otters recolonized Bering Island by dispersal from Mednyi in the mid-1970s. By 1984, the population at Bering Island had reached about 1,500 individuals, and was still increasing (A. Zorin, pers. comm.).

Univariate comparisons. - After establishing the infraspecific classifications by using the multivariate analyses, each character was reexamined to determine its utility in differentiating between the three subspecies. For both sexes, the easiest populations to distinguish from each other are those from the USSR and California. These are the forms at the ends of the range. For both sexes, $95 \%$ confidence intervals of the means of 10 mensural characters do not overlap in comparisons between these two samples (Table 2). The $95 \%$ confidence levels of means of seven mensural characters do not overlap in both sexes in comparisons between the groups from Alaska and California. Between the Alaskan and the USSR groups, the $95 \%$ confidence levels of means of seven characters in females and of three characters in males do not overlap (Table 2).

For most characters, individuals from the USSR average largest, those from California smallest, 


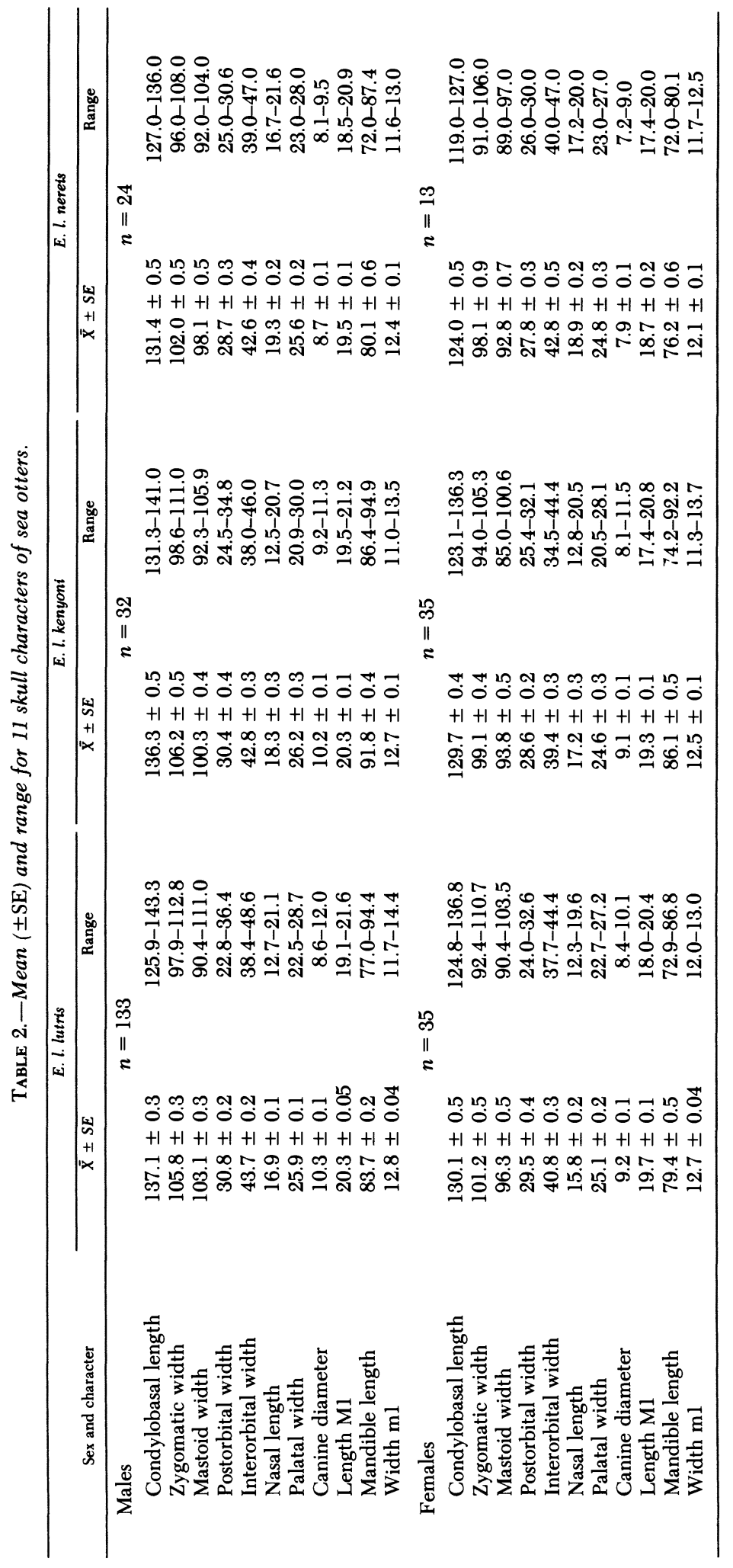


and those from Alaska intermediate. The character showing the most striking difference among subspecies is mandibular length, an exception to the common pattern (Table 2). Mean mandibular length is longest in Alaskan animals, shortest in those from California, and intermediate in the USSR sample.

There is overlap in the ranges of all characters (Table 2), which indicates the difficulty in identifying individuál animals of unknown provenance without resorting to multivariate analysis. However, the three subspecies can be distinguished statistically by using a sufficiently large sample to provide reliable mean measurements of individual characters, or by combining some sets of characters into a multivariate analysis.

\section{TAXONOMY \\ Genus Enhydra Fleming}

1758. Mustela Linnaeus (in part).

1772. Lutra Brünnich (in part).

1777. Lutra Erxleben (in part).

1822. Enhydra Fleming. Type species Enhydra marina Fleming, 1822, by monotypy.

1827. Latax Gloger. Type species Lutra marina Erxleben, by monotypy.

1829. Enydris Fischer. Invalid emendation of Enhydra Fleming, 1822.

1831. Phoca Pallas (in part).

\section{Enhydra lutris (Linnaeus)}

Synonymy under subspecies.

Holotype.-None exists. Linnaeus (1758) based the description on Steller's (1751) account. Thomas (1911) restricted the type locality to Kamchatka. Barabash-Nikiforov (1947) argued cogently that the type locality should be restricted to the Commander Islands, because most of Steller's (1751) observations were from Bering Island in 1741. Because Barabash-Nikiforov (1947) failed to mention and specifically refute Thomas' earlier restriction, the type locality remains Kamchatka.

Geographic distribution.-Originally known from Japan in the western Pacific through the Kuril Islands, along the Kamchatka peninsula, the Commander Islands, the Aleutian Islands, and in the eastern Pacific along the coast of Alaska southward to Baja California. Presently known from the Kiritappu Peninsula of eastern Hokkaido Island (Nakata, 1986) in the west to southern California in the east.

Description.-Body shape elongated and cylindrical, an obvious adaptation to aquatic life; total length $\leq 150 \mathrm{~cm}$, length of tail $\leq 35 \mathrm{~cm}$, weight $\leq 45 \mathrm{~kg}$; head large and blunt; eyes small; vibrissae long; nostrils capable of closing underwater; short, pointed ears that also close; neck short and thick; forelimbs with short, fused digits; foreclaws short and retractile; hind limbs flipperlike and covered with short hair; outer hind toe longest, inner shortest; overall color variable from almost black to almost red; head and abdominal region somewhat paler than dorsum; base of hair on dorsum, flanks, and limbs grayish, becoming browner distally and darkest at the tip; pronounced grizzling in some individuals; underfur long, dense, and silky; guard hair sparse, about $30 \mathrm{~mm}$ long on dorsum; tail flattened dorsoventrally, muscular, and tapering distally; skull short (maximum $150 \mathrm{~mm}$ ) and broad (maximum $113 \mathrm{~mm}$ ); upper outline of skull slightly convex; braincase low and broad with prominent sagittal and occipital crests and mastoid processes; postorbital processes small; tympanic bullae small and transverse with tiny auditory meati; rostrum short, truncate anteriorly, and flat dorsally; nasal bones short and broad and nasal aperture large; infraorbital foramina about equal in size to canine alveoli; coronoid process high and sloping posteriorly, with convex anterior and concave, straight, or convex posterior borders; palate broad and extending posteriorly past molars; dental formula i $3 / 2, \mathrm{c} 1 / 1, \mathrm{p} 3 / 3, \mathrm{~m} 1 / 2$, total 32 ; molars flat and broad; P4 molariform, but others smaller; anterior premolar larger than posterior premolars and molars; os penis long (maximum, $150 \mathrm{~mm}$ ), massive, and thick (maximum, $15 \mathrm{~mm}$ );

Measurements.-Listed in Table 2.

The following description was prepared by Don E. Wilson: 
TABLE 3.-Percent of individuals with indicated degree of development of frontal notch in three subspecies of sea otters.

\begin{tabular}{lrrrr}
\hline Subspecies and sex & $n$ & $\begin{array}{c}\text { Absent } \\
(\%)\end{array}$ & $\begin{array}{c}\text { Suggested } \\
(\%)\end{array}$ & $\begin{array}{c}\text { Present } \\
(\%)\end{array}$ \\
\hline E. l. lutris & 195 & 4 & 33 & 63 \\
$\quad$ Females & 48 & 13 & 13 & 74 \\
Males & 147 & 1 & 40 & 59 \\
E. l. kenyoni & 71 & 1 & 14 & 85 \\
$\quad$ Females & 36 & 3 & 8 & 89 \\
Males & 35 & & 20 & 80 \\
E. l. nereis & 38 & 71 & 21 & 8 \\
Females & 14 & 57 & 29 & 14 \\
Males & 24 & 79 & 17 & 4 \\
\hline
\end{tabular}

Enhydra lutris kenyoni, new subspecies

Holotype.-An adult female, USNM 527045, tanned skin with skull and mandibles removed and cleaned, obtained between January and May, 1959, by Karl W. Kenyon (original number KWK 59-17). The skin is in good condition except for some small holes in the dorsum. The mandibles are separated and the teeth are well worn.

Type locality.-Amchitka Island, Alaska, USA.

Geographic distribution.-Throughout the Aleutian Islands, originally as far north as the Pribilof Islands and in the eastern Pacific Ocean from the Alaskan Peninsula south along the coast to Oregon. This subspecies was extirpated from the Pribilof Islands, and naturally occurring populations are no longer found south of Prince William Sound, Alaska. Animals have been reintroduced from these original populations to the Pribilof Islands, southeastern Alaska, British Columbia, Washington, and Oregon, with varying degrees of success (Jameson et al., 1982). The reintroductions to Oregon and to the Pribilof Islands were unsuccessful. The populations in southeastern Alaska and British Columbia are well established, and the population in Washington is small but growing. Additional details on the present status of the southeastern Alaska, British Columbia, and Washington populations can be found in Estes (in press).

Diagnosis.-From E. l. lutris, E. l. kenyoni differs as follows (Table 2): overall skull length slightly shorter, but nasal length longer. Mandibles longer, averaging $67 \%$ of condylobasal length compared to $61 \%$ in the nominate form. E. l. kenyoni differs from E. l. nereis as follows: overall skull length greater, but nasal length shorter; skull narrower in most measurements except for postorbital width; teeth larger. Mandibles longer, averaging only $61 \%$ of condylobasal length in E. l. nereis.

Description.-Skull medium-sized in most measurements compared to the other two subspecies, but comparatively longer mandibles. A prominent frontal notch (Roest, 1973) present in most adults (Table 3). Mandibles long, averaging two-thirds the condylobasal length. Color varies from shades of brown through black, with the head and neck much paler. Sparse guard hairs dark or silvery grey, giving grizzled appearance to some individuals.

Measurements.-Measurements (in $\mathrm{mm}$ ) of the holotype are as follows: condylobasal length, 129.2; zygomatic width, 99.5; mastoid width, 93.2; postorbital width, 26.2; interorbital width, 39.0; nasal length, 16.4; palatal width, 25.5; canine diameter, 9.2; upper first molar length, 19.1; mandible length, 84.3; lower first molar width, 12.4. Means and ranges of all specimens examined are listed in Table 2.

Etymology.-I take great pleasure in naming this subspecies in honor of Karl W. Kenyon, whose studies on the populations composing this subspecies form the chief contribution to our knowledge of sea otters in Alaskan waters.

Specimens examined (84, USNM unless otherwise marked).-Alaska: Amchitka Island, 30 males, 30 females; Kavalga Island, 1 male; St. Paul, Pribilof Islands, 1 male; Sanak Island, 1 female; Shumagin Islands, 3 males, 3 females; Alaska Peninsula, 1 male; Kodiak Island, 1 male; 
Prince William Sound, 3 males, 3 females; unknown, 1 female; British Columbia: Vancouver Island, 2 males (RBCM); Washington: Pt. Granville, 1 male; Straits of Juan de Fuca, 1 female; Oregon: Port Orford, 2 females. All specimens from British Columbia, Washington, and Oregon were collected before reintroductions.

\section{Enhydra lutris lutris (Linnaeus)}

1758. [Mustela] lutris Linnaeus. Type locality "Asia \& America septentrionali," restricted to Kamtchatka by Thomas (1911:138).

1777. [Lutra] Marina Erxleben. Type locality "Asia septentrionali atque America."

1800. Lutra gracilis Bechstein. Type locality "Statenland."

1822. Enhydra marina Fleming. Probably based on Lutra marina Steller (Palmer, 1904).

1827. Lutra Stelleri Lesson. Type locality "les environs du pôle boréal."

1829. E[nydris]. Stelleri: Fischer, p. 229. Name combination.

1829. E[nydris]. ? gracilis: Fischer, p. 229. Name combination.

1831. Phoca lutris: Pallas, p. 100. Name combination.

1843. Enhydra lutris: Gray. First use of current name combination.

Holotype.-None exists. Linnaeus' (1758) type locality “Asia \& America septentrionali” restricted to Kamchatka by Thomas (1911:138).

Geographic distribution.-Restricted to the western Pacific from the Commander Islands in the north through the Kuril Islands in the south. Formerly as far south as northern Japan.

Diagnosis.-The nominate form differs from E. l. kenyoni as follows: skull measurements greater in most dimensions, with the exception of nasal length and mandibular length. The nominate form differs from $E$. $l$. nereis as follows: skull measurements greater in most dimensions, with the exception of nasal length; in addition, most adults have a moderately or well-developed frontal notch in the postorbital region (Table 3).

Description.-Braincase relatively long and broad, but rostrum short. Frontal notch moderately developed in postorbital region of most adults (Table 3). Mastoid processes well developed, lending bulk to overall breadth of skull. Other features as in species description.

Measurements.-Means $( \pm S D)$ listed in Table 2.

Specimens examined (236, TINRO, unless otherwise marked).-Kuril Islands: Iturup, 5 males, 5 females; Uruppu, 15 males, 20 females; Chernye Brabya, 1 male; Onnekotan, 5 males, 3 females; Paramushiro, 22 males, 12 females; Shumushu, 2 males, 2 females; Kamchatka: Lopatka Point, 48 males, 8 females; Commander Islands: Bering Island, 79 males, 4 females; Copper (Mednyi) Island, 1 male, 1 female (USNM); Asian Pacific: Unknown, 3 males (1 NSM, 1 USNM).

\section{Enhydra lutris nereis (Merriam)}

1904. Latax lutris nereis Merriam.

1923. Enhydris lutris nereis: Grinnell, p. 316. First use of current name combination.

Holotype.-An adult male, USNM 133508, skull and complete skeleton, obtained 2 July 1904, by Geo. M. McGuire on San Miguel Island off the coast of California.

Geographic distribution.-Most of the established population is centered off the coast of California between Santa Cruz and Pismo Beach, with widely scattered sightings north and south of the range. Formerly extended south as far as Morro Hermoso, Baja California, Mexico, and throughout the Channel Islands. Recently (1987) reintroduced to San Nicolas Island.

Diagnosis.-Enhydra l. nereis differs from E. l. lutris as follows: overall skull length shorter, but nasal length longer; skull narrower in most measurements, but females average wider interorbitally; frontal notch absent; mandibles shorter; teeth smaller. $E$. $l$. nereis differs from $E$. $l$. kenyoni as follows: overall skull length shorter, but nasal length longer; skull narrower in most measurements; interorbital width greater in females; palatal width greater; teeth smaller; mandibles considerably shorter.

Description.-Skull relatively small but broad, with short braincase but long rostrum. Nasals long. Frontal notch rarely well developed in adult animals (Table 3), resulting in relatively broad postorbital region, especially in females. Interorbital region also relatively broad. 
Measurements.-Means $( \pm S D)$ listed in Table 2.

Specimens examined (48).-California: Monterey, 3 males (1 AMNH, 1 SBMNH, 1 SDMNH), 2 females (1 PGM, 1 LLU); Hopkins Marine Station, 1 male (CPSU); Carmel, 1 female (CFG); South Carmel River, 1 female (CFG); Asilomar, 2 males (1 CFG, 1 PGM); Point Lobos, 1 male (MVZ), 2 females (1 CFG, 1 MVZ); Gorda, 1 female (MVZ); Morro Bay, 8 males (3 CFG, 1 CPSU, 3 MLML, l CAS); San Luis Obispo County, 1 female (MVZ); San Miguel Island, 1 male (USNM); Unknown, 9 males (4 CFG, 4 MVZ, 1 SSU), 5 females (2 CFG, 1 MLML, 2 MVZ).

\section{ACKNOWLEDGMENTS}

We are grateful to Y. D. Vorobijov and Y. V. Serepyeva of the Pacific Scientific Research Institute of Fisheries and Oceanography for assistance during our study of specimens in the Soviet Union. M. Yoshiyuki and N. Miyazaki allowed us to examine specimens in the National Museum in Tokyo, Japan. Earlier drafts of the manuscript were reviewed by A. L. Gardner, W. Z. Lidicker, Jr., and A. I. Roest. We are particularly grateful to Dr. Roest for the data he used in his earlier sea otter studies. J. D. Smith extracted a bug from the $\mathrm{BIO} \sum \mathrm{TAT}$ program at a critical juncture in our studies.

\section{Literature Cited}

Barabash-Nixiforov, I. I. 1947. Kalan. Pp. 1-174, mals of California. University of California in Soviet Ministrov RSFSR. Glavnoe upravlenie po zapovednikam. The sea otter. [Translated from Russian by A. Birron and Z. S. Cole for the National Science Foundation by the Israel Program for Scientific Translations, Jerusalem, 1962, 227 pp.].

Bechstein, J. M. 1800. Thomas Pennant's Allgemeine übersicht der vierfüssigen Thiere. Verlage des Industrie-Comptoir's, Weimar, 2:1-666.

BRÜNNICH, M. T. 1772. Zoologiae Fundamenta. Grunde i Dyreloeren, Hafniae et Lipsiae, 253 pp.

Burdin, A. M. 1988. Population structure of sea otters (Enhydra lutris) of Kamchatka and the Commander Islands [In Russian]. Nauchno-Issled. Raboty po Morskom Mlekopitajushchim Severnoj Chasti Tikhogo Okeana v 1986-1987 gg., Minist. Rybn. Khozj. SSSR, Vsesojuz. Nauchno-Issled. Inst. Morsk. Rybn. Khozj. i Okeanogr. VNIRO:162-173.

Davis, J., AND W. Z. Lidicker, JR. 1975. The taxonomic status of the southern sea otter. Proceedings of the California Academy of Sciences, Fourth Series, 40:429-437.

ESTES, J. A. In press. Growth and equilibrium in sea otter populations. Journal of Animal Ecology.

ERXlebeN, J. C. P. 1777. Systema regni animalis. Mammalia. Impensis Weygandianis, Lipsiae, 636 pp.

FisCHER, J. B. 1829. Synopsis mammalium. J. G. Cottae, Stuttgart, $752 \mathrm{pp}$.

Fleming, J. 1822. The philosophy of zoology. Archibald Constable \& Co., Edinburgh, 2:1-618.

GLOGER, C. 1827. Bemerkungen über ein Paar schlesische Säugethierarten, Sorex pygmaeus Laxm. et Pallas,-? Sorex etruscus Savi, und Lutra lutreola Ill. Nebst Einigen Worten über die MeerOtter, Lutra marina auct., als Typus einer eignen Gattung. Nova acta Academiae Caesareae Leopoldino-Carolinae Germanicae Naturae Curiosorium, 13:479-512.

Gray, J. E. 1843. List of the specimens of Mammalia in the collection of the British Museum. British Museum (Natural History), London, $216 \mathrm{pp}$.

GrinNELl, J. 1923. A systematic list of the mamPublications in Zoology, 21:313-324.

Grinnell, J., J. S. Dixon, ANd J. M. Linsdale. 1937. Fur-bearing mammals of California. University of California Press, Berkeley, 1:1-375.

Harris, C. J. 1968. Otters, a study of the recent Lutrinae. Weidenfeld and Nicolson, London, 397 pp.

$\rightarrow$ Jameson, R. J., K. W. KenYon, A. M. Johnson, AND H. M. WIGHT. 1982. History and status of translocated sea otter populations in North America. Wildlife Society Bulletin, 10:100-107.

Kenyon, K. W. 1969 . The sea otter in the eastern Pacific Ocean. North American Fauna, 68:1-352.

Lesson, R. P. 1827. Manuel de Mammalogie. Roret, Paris, $441 \mathrm{pp}$.

LiNNAEUS, C. 1758. Systema naturae per regna tria naturae, secundum classes, ordines, genera, species, cum characteribus, differentiis, synonymis, locis. 10th ed. Laurentii Salvii, Uppsala, 1:1-824.

Merriam, C. H. 1904. A new sea otter from southern California. Proceedings of the Biological Society of Washington, 17:159-160.

NakatA, C. 1986. Eastern Hokkaido-Kiritappu. Animal Magazine of Natural History, 163:12 [in Japanese].

OGNEv, S. I. 1931. Zveri Vostochnoi Evropy i Severnoi Azii. Vol. II Carnivora (Fissipedia). GlavnaukaGosudarstvennoe Izdatel'stvo, Moscow, 776 pp. [Mammals of eastern Europe and northern Asia, translated from Russian by A. Birron and Z. S. Cole for the National Science Foundation and the Smithsonian Institution by the Israel Program for Scientific Translations, Jerusalem, 1962, 590 pp.].

OxEN, L. 1816. Lehrbuch der Naturgeschichte. A. Schmid, Jena, 3(2):1-1270.

Pallas, P. S. 1831. Zoographia Rosso-Asiatica. Petropoli, St. Petersburg, 1:1-568.

Pennant, T. 1793. History of quadrupeds. Third ed. B. White, London, 2:1-324.

Pimental, R. A., AND J. D. Smith. 1986. BIO $\sum$ TAT II. A multivariate statistical toolbox. Second ed. Sigma Soft, Placentia, California, 212 pp. 
Roest, A. I. 1971. A systematic study of the sea otter (Enhydra lutris). Proceedings of the Eighth Annual Conference on Biological Sonar and Diving Mammals, Biological Sonar Laboratory, Marine Mammal Study Center, Fremont, California, $1: 133-135$.

1973. Subspecies of the sea otter, Enhydra lutris. Contributions in Science, Natural History Museum of Los Angeles County, 252:1-17.

1976. Systematics and the status of sea otters, Enhydra lutris. Bulletin of the Southern California Academy of Sciences, 75:267-270.

1985. Determining the sex of sea otters from skulls. California Fish and Game, 71:179183.

SCHEFFER, V. B., AND F. WiLKe. 1950. Validity of the subspecies Enhydra lutris nereis, the southern sea otter. Journal of the Washington Academy of Sciences, 40:269-272.

Shaw, G. 1800. General zoology. Mammalia. G. Kearsley, London, 1(2): 1-542.
Steller, G. W. 1751. De Bestiis Marinis. Novi Commentarii Academiae Scientiarum Imperialis Petropolitanae, 2:289-398. [Translated from Latin by W. and J. E. Miller, Pp. 179-218, in Fur seals and fur seal islands of the north Pacific Ocean by D. S. Jordan et al., United States Treasury Department, Document 2017, Part 3, 1899].

Stroganov, S. U. 1962. Zveri Sibiri: khishchnye. Akademiya Nauk SSSR. Sibirskoe Otdelenie. Biologicheskii Institut, Moscow [Carnivorous mammals of Siberia, translated from Russian by A. Birron, published for the Smithsonian Institution and the National Science Foundation by the Israel Program for Scientific Translations, Jerusalem, 1969, 522 pp.].

Tномаs, O. 1911. The mammals of the tenth edition of Linnaeus; an attempt to fix the types of the genera and the exact bases and localities of the species. Proceedings of the Zoological Society of London, 1911:120-158.

Submitted 15 September 1989. Accepted 1 February 1990. 